\title{
Reification in Revolution 2020
}

\author{
Sajid Mehmood ${ }^{1}$ \\ ${ }^{1}$ National University of Modern Languages, Islamabad, Pakistan \\ Correspondence: Sajid Mehmood, National University of Modern Languages, Islamabad, Pakistan. E-mail: \\ s.mehmood2006@yahoo.com
}

Received: March 5, 2018 Accepted: March 28, 2018 Online Published: May 5, 2018

doi:10.5539/ijel.v8n5p43 URL: https://doi.org/10.5539/ijel.v8n5p43

\begin{abstract}
This research study deals with the in-depth meanings of reification and their relevancy with the text of the novel Revolution 2020 written by Chetan Bhagat. Reification is a common perception and a specific ideology of people living in a capitalist society. It hides some facts and propagates some deceptive ideas in the society. The study of reification exposes the essence of social reality. It reveals how various aspects of capitalism seem natural and general with human beings. It is a methodical strategy to understand the mind and action of the people. Along with the further analytical examination of reification, this study explores the thoughts, feelings and actions of the people in the novel. The interactions of the characters have been explored with reference to reification. Analysing reification deeply, I have investigated the nature of prevalent assumptions and their relationship with human interaction. The illusionary elements of capitalist society portrayed in the novel have been analysed. Textual analysis is the appropriate research method for this study.
\end{abstract}

Keywords: dehumanization, false consciousness, rationalisation, selfishness, thingification

\section{Introduction}

Reification is the ideological matter of capitalist society. Marx and Lukacs point out the presence of reification in capitalism (Lukacs, 1971). It is a representation of social consciousness which identifies the human relationships with thing-like characteristics. Almost all the aspects of society are influenced by commodity exchange. The prevalent ideas in society are shaped by commodity form. Accordingly, the social structure of capitalist society involves reification. Human relationships are reified relationship. Lukacs visualises that "natural laws" of capitalism indoctrinates human consciousness (1971). Consequently, atomisation of individual occurs in society and almost every person is a separate being. Under the impact of commodification, objectification of social relationship is the dominant phenomenon in capitalist society.

In this paper, I have investigated Chetan Bhagat's novel Revolution 2020 with reference to reification. The novel presents a story of corruption and love in a capitalist society of India. Reification is very likely in capitalism. It is a social issue of the modern capitalist society. A novel, being a genre of literature, reflects people in a certain society and thus gives an impression of reality. Therefore, the basic issue behind this study is the necessity of investigating reification as a social phenomenon in the novel. The focus is on the interaction of the characters and they behave like real human beings. Hence, the characters of the people in the novel and their relations with each other have been probed to understand the reification. They act according to the principles of capitalism. In this context, the underlying research questions are (a) How do the people in the novel either degenerate themselves or enhance their values. (b) What misconceptions or false beliefs of the characters caused by capitalism are delineated in the novel? (c) How do the characters behave in the state of reification and how does the social structure delineated in the novel tend to reification?

\section{Literature Review}

A person under the effect of reification demonstrates instrumental handling of others and views his own abilities from the standpoint of profitability. In this context, Lukacs assumes that in capitalist society almost every individual acquires the habit of observing himself and the world around as sheer things or objects. Hence, reification is a perceptual category in which an individual's natural surroundings, social setting, and personal traits are understood or imagined in a simply separate and unemotional way. This is the thing-like attitude towards oneself and the world both.

Referring to the internal spirit of reification, Honneth (2005) points out that the interaction among the characters 
outlined in some of the recent novels is like a human treatment with the lifeless things. They have not any sentimental approach towards each other. In his view, reification is "a modified form of human behaviour". (p. 93)

There is hardly any difference between human interaction and a person's handling of inanimate objects. It suggests that human beings are not given their deserving status. Rather, things are regarded more valuable than people. The people are means to gain some materialistic advantages. This idea is expressed by Nussbaum (2000) through the term "objectification". He is of the view that reification is unethical, as it considers human beings commodities and lifeless things. They are treated like senseless robots without any human feelings. Honneth adds that reification involves deviation from a real posture towards the world. (p. 94)

Val Burris (1988) interprets that Marx's idea about reification is concerned with social consciousness. Under the sway of capitalism, human beings develop a collective consciousness in which human relations are given the characteristics of things. For Marx and Lukacs both, the social consciousness is an unavoidable phenomenon and seems natural with human beings. The theory of reification diagnoses the reciprocal connection between the social structure and social consciousness. The social consciousness is often a victim of illusion because the people usually cannot see beyond the seeming reality. Referring to this element Marx (1959) states: "All science would be superfluous if the outward appearance and the essence of things directly coincided". (p. 592).

The statement indicates that there is an obvious distinction between appearances and reality. The social consciousness is by and large a false consciousness. Therefore, it is the question of real values and the values assumed as truth in society. The social interaction among the people is frequently an outcome of deceptive assumptions.

Walker \& Gray (2007) state that people tend to rationalisation, measurability and calculability in a state of reification. The people are observed as commodities or objects. Postone (2003) regards commodity form the responsible factor of spreading rationalisation in society. The system of commodity production regulates the people and they depend upon things. Reification incorporates the Marxist theories of commodity fetishism and alienation also.

Raymond (2008) directly associates reification with the ailment of society in which individuals "treat themselves and others, as if they were things, not people" (p. 123). Certainly, these views are erroneous, and any approach based on such assumptions is a misguided approach towards the humankind. The thingification of human beings entails the typical characteristics of capitalism like selfishness, individualistic approach, thirst for profit and tendency to exchange, etc. It is a result of the people's selfish attitude of not looking at any aspect beyond their own advantages. But, before declaring any belief false, we need to find out the true belief. As the knowledge of reality is relativist to a certain society, it is difficult to find out the universal truth. However, the essence of human nature helps us in grasping the truth. Selfishness is caused by human needs. To have food and shelter is the biological need of human beings. Their desires for seeking profit is based on the accomplishment of their needs. But one should be careful about the needs of others also. Human beings live in society where they need to cooperate with each other and this cooperation should not be based on sheer selfishness. To squeeze and exploit others for one's own advantages is not pertinent to human beings. On this ground, selfishness and profit orientation in all matters are the causes of reification and deviation from the standards of human nature produces it. Geuss (2008) thinks that Lukacs views capitalism as a promoter of false concepts and reification uncovers the ideological deceptions in the society. Thus, reification is a medium to understand the components of social reality fully based on outward appearances.

Pitkin (1987) thinks that reification means treating abstract ideas as something physical, concrete, substantial, and real. Similarly, Woodard (2005) calls conferring tangibility, physicality or concreteness on some abstraction. The dictionary of Marxist thought (Bottomore, 1991) defines reification in these words,

The act (or result of the act) of transforming human properties, relations and actions into properties, relations and actions of man-produced things which have become independent (and which are imagined as originally independent) of man and govern his life. Also, transformation of human beings into thing-like beings which do not behave in a human way but according to the laws of the thing-world. Reification is a "special case of alienation, its most radical and widespread form characteristic of modern capitalist society". (p. 463)

Reification works in multiple ways. It is the transformation of human beings into things and the bestowing of human properties on things. It is about giving things an extra weightage or importance and reducing the importance or weightage of human beings. Reification reduces the values of human beings and increases the values of things. It is about the degradation of human beings. Things gain so much power that they govern human life. Things are inanimate, and they have not power to increase or decrease their own values. Of course, 
human beings increase or decrease the values. Another fact is that a single person has not power enough to enhance or diminish the value of things in a society. Of course, unification of thoughts is involved in the process of enhancing the values of things and decreasing the values of human beings. It is the collective belief system that prevails in society through imitation of each other. It is the ideology of capitalist society.

If a person's attitude towards the people around him is based on alienation and rationality without respecting their feelings, he is under the impact of reification. Human beings need things for survival and the things do not need human beings, but the things have become regulator of human beings according to Lukacs. A person uses things for his facilities. People want to gain as much facilities in life as possible for them. To gain facilities, they want to own things. They desire to get all types of things in abundance. To get things, they want to earn and accumulate wealth. Almost everyone wants to own much money and property. In the pursuit of wealth, a person becomes selfish, greedy and profit-seeker. It is the degradation of human values. The degradation occurs because of the combination of desire and human needs. Consequently, things acquire more importance, value and weightage, as everyone seems to possess them almost emotionally. It is the stage of reification where things govern human beings because the people are their followers and passionate devotees. It is also a commodity fetishism called by Marx. In this way, commodity becomes a manipulator of human life and it sinks deeply into human consciousness, according to Lukacs. Reification is an investigative tool to examine all these facts of capitalist society.

David Walker and Daniel Gray clarify the concept of reification. They synonymise it with dehumanisation. The dehumanisation and thingification of human beings under the power of social structure have almost the same connotation. Lukacs believes that the people are victims in this system and they lose their quality of being human. "Human qualities, relations, actions and even human beings themselves are transformed in the course of capitalist production into things, and these things come to have power over human beings". (Walker \& Gray, 2007, pp. 194, 255)

The social system makes the people unemotional beings struggling for the fulfilment of their own self-interests. They are the followers of calculability and rationalisation. The system governs us and we helplessly act within certain limitations. Commodity exchange influences almost all social interactions. The things have power upon us due to the significance of commodity. The commodity is a managing force of human action. Therefore, thingification means commodification of human actions, relations and thoughts. Reification sinks into human consciousness so deeply that the people lose their essentials typical for humanity. They are almost perfectly under its sway. The virtues proper to meet the needs of competitive environment are appreciated in society. Walker and Gray comment that people's creativity, spirituality and imagination are affected by commodification, because they do not find opportunities to decide and work according to their own free choices. Their activities are imposed on them by the dire circumstances of their lives. This lack of will in one's activity is alienation according to Marx and the activities are usually based on some compulsion. The people struggle to gain some abilities, skills and competency to perform the activities under compulsions and establish a relation of detachment between themselves and their activities. It is likely that whatever they do, they do for some materialistic purposes. As a result, they lose the emotional aspect of their personalities and acquire the fruits of detached activities based on rationalisation.

Lukacs locates the basic element of reification in the Marx's theory of commodity fetishism. In commodity fetishism, social relations among people are presupposed as "the fantastic form of a relation between things". (p. 86) Feenberg (2015) explains that in the reified world, people's relationship with society is like the relationship with natural objects. For Feenberg, reification is fragmentation. The people are away from each other. They are not viewed as members of some family, group or society. Rather, they are individuals. Like people, all the institutions in society are separate from each other and have their own laws (p. 493). Marx's theory of alienation also represents this concept of separateness among individuals.

\section{Methodology}

I have developed the theoretical framework from the reviewed literature. It has constructed the conceptual foundations of analysis, interpretation and explanation. It includes the major characteristics of reification. The interaction of the characters in the novel has been explored with reference to reversal of values, false consciousness, dehumanisation, depersonalisation, thingification, devaluation and objectification of human beings. These are the various aspects of reification and they overlap each other. The causes and the consequences of these aspects have also been analysed. Similarly, the altruistic and individualistic elements have been investigated with reference to reification.

I have chosen textual analysis as a research method. The text of the novel has been analysed meticulously in the 
light of the theoretical framework derived from Lukacs' theory of reification. Catherine Belsey (2005) writes about textual analysis,

There is no such thing as "pure" reading: interpretation always involves extra-textual knowledge. Some of this is general, part of the repertoire of knowledges that constitutes a culture; some of it is personal, a matter of one's own interests or biography; and some of it is derived from secondary sources. (p. 160).

The statement obviously guides researchers to bring their previous knowledge to analyse and interpret the text of literature. Again, she describes about textual analysis as a strategy to produce ideas in a new way. "It is much more likely to involve assembling ideas that have not been brought together in quite that way before." (p. 160).

\section{Analysis and Discussion}

In the very prologue of the novel, we encounter Gopal - the successful man in the capitalist Indian society. Being the director of Ganga Tech college, he earns lots of wealth and lives splendid life. Having the individualistic and competitive aptitudes, he appears a typical figure of capitalism. The prologue of the book gives us impression that we are about to read a story of a man who achieves a higher status in the society. Gopal entertains inaccurate beliefs and follows the apparent fashion of capitalism. The college GangaTech is his property and Education is a commodity for him from which he earns. For him enjoying whiskey and accumulation of wealth are the ultimate ends. He proudly tells about his income and suggests Chetan to follow his course of life.

"live life. Start having fine whisky. You will develop a taste!" (p. 3)

To the warning given by Chetan about spoiling himself in drinking wine, he answers.

"Why dangerous! Who is going to fucking cry for me? If I live, I want to enjoy. If I die, who cares?" (p. 5)

His idea of enjoying life is a reified concept of a pessimist person who drinks to get rid of his despair. The activity which he calls a source of joy brings disappointment for him and it is not sufficient to enjoy the luxury of things only. He lives a lonely life and in spite of having all the facilities around him, he lacks in something. To fulfill this shortcoming, he drinks heavily. "Gopal's hand trembled as he continued to pour his drink. I wondered if I should stop him from drinking more." (5). Gopal drinks to forget the sorrow of his love because he has lost Aarti forever. His heavy drinking makes Chetan realise that some terrible fact exists in his past. In a state of extreme richness, a vacuum exists in his life. He is alone in a well-furnished huge bungalow. He is a single young boy without any friend, wife and any sincere relative. As he himself tells "successful people don't have friends". His remark about the successful people entails the individualistic and selfish ideology of capitalism. In the capitalist society, people typically fulfill their own selfish motives and ignore the needs of others. They do not have cordial relations with each other. Their relations are based on the exchange of commodities. It is the commodification or objectification of human relationship. This assumption is hardly true because it is almost impossible to see every person as a follower of his/her own selfishness. Gopal's companion Chetan is a major example of a person with altruistic spirit. Chetan does not leave him in his critical state of drunkenness. He brings Gopal to hospital and spends the night with him. it is the act of sympathy and kindness without the involvement of any selfish or opportunistic intention behind it. It is an evidence that everyone cannot be selfish. In a state of drunkenness, Gopal is helpless and needs hospital with the help of his friend. In this critical situation, his money cannot serve him. It suggests that a person is not sufficient for himself in all the matters and he needs cooperation from others. All needs of a person cannot be accomplished solely by money and property. Reification lies in thinking that one can fulfill all the necessities with money and property. A person needs sympathy and friendship beyond the accumulation of wealth. The ironical situation is that Gopal gives remark against friendship, while his friend helps him and hospitalises him. Gopal's idea about "the successful people" represents his inner thoughts fully developed in the capitalist environment. Selfishness of human beings cannot be a common truth of human nature. Reification exists in applying this idea on the whole humanity and generalising all the people as the followers of the same goal, while the fact is that selfishness can be the relational truth of a capitalist culture and Gopal's assumption about the successful people may be true with reference to his own society. His misjudgment is also concerned with the idea of success. In his opinion, a wealthy person is successful while the reality is that his own money with which he buys whisky damages his health and he gets recovery with the assistance of a man having altruistic spirit. So, considering a wealthy one a successful person in all respects is a fallacious belief which causes reification.

He makes many requests to the author to go to his home and drink with him. It suggests he is thirsty for some company and drinks to remove the pangs of loneliness. Accumulating wealth and drinking are his major activities. Materialistically, he is very successful, but spiritually and emotionally, his personality is imbalanced and disturbed. It alludes that capitalism is not sufficient in fulfilling all his needs. His existence in a state of 
drunkenness implies that making struggles for materialistic success only is not a right creed. It challenges Smith's idea about human nature that it is prone to barter and exchange. $(2005$, p. 19) He drinks to remove the sufferings of hard reality. His current situation is a result of his following the ways of capitalism. The ways of capitalism are led by the ideological torch of individualism, selfishness, self-interest, competition and exploitation, etc. On the track of capitalism, he gains almost all the facilities of life but lacks in internal spiritual satisfaction, which he attempts to achieve, perhaps falsely, from drinking whiskey. The facilities of life are provided by capitalism, but human life is not limited to gain these facilities only. His internal dissatisfaction is a symbolic announcement that attempting to earn throughout one's life by using all the fair and unfair means is not a real practice of human nature. Earning livelihood is a human need, but it cannot be the sole purpose of life. It is true that human beings need money but restricting oneself to work wholly for gaining it all the time is in fact a fallacious concept that leads to reification.

Aarti starts loving him when he was poor and she leaves him because his indulgence in the immoral activity of having a sexual affair with the two prostitutes is intolerable for her. She cannot forgive the moral flaw in his personality but she misjudges him in her own way. Aarti is failed in understanding the nature of relationship between Gopal and the prostitutes. He is not sexually a loose character. He does so just for fashion and the girls express their astonishment that he is not handling them properly. In fact, he follows the ways of the rich people without fulfilling his sexual lust and wants to include himself into the higher Indian social class. In his mind, it is the issue of entering higher social stratification. This facet of his personality is misjudged by Aarti and she abandons him. It is the result of following the appearances without grasping the underlying reality. The moral flaw is the result of his becoming a rich man because he thinks that all the rich do so. In his poverty, he gains his beloved and in a state of his extreme richness, he loses her for good. His wealth causes his emotional disturbance and almost ruins his life. It suggests that too much dependency on property and wealth is not a very right assumption and the ownership of a very huge property does not always bring happiness to its owner. Occasionally, it makes a turmoil in one's life. It is the rejection of an established idea in capitalist societies that wealth and property are the sources of comfort, pleasure and success. Had Gopal not been rich, he would not have been able to buy the company of prostitutes to lose his beloved. His wealth brings disappointment for him and provides him freedom to be involved with the prostitutes.

Parents play their own roles in the mental growth of their children. Gopal's personality is much influenced by the poverty of his father. His very first act of stealing Aarti's cake is caused by his poor background because his father cannot afford the lunch-box for his son. The father entertains his own false beliefs and assumptions. As a matter of fact, these beliefs are generated into the minds of people by seeing the actions and thoughts of each other. The father is not ready to sell a piece of his land to meet his needs. Neither he wants to get his medical treatment by selling his land. Instead, he thinks that he will never sell his land in his life. "I am a farmer's son. I am not giving up my land. Not until I die". (15). Considering land, a sign of honour without using it for getting some profit or fulfilling the needs of life is not a right idea. Land is a property and any property of a person is useful for him, if he gets some benefit from it to satisfy his needs, but considering a dead or dormant property a source of respect and selling it for the accomplishment of needs a sign of insult is a false assumption. The false assumption of Gopal's father is evident in this statement. "A former doesn't insult his land. He doesn't sell it either." (35) He ignores his own illness and lies on bed to wait for death. The property which Gopal uses to accumulate wealth by unfair means with the help of Shukla ji could have been used earlier with honesty but the false faith of his father about the land was a resistance in his way. The father pushes his son into a competition of engineering for which he is not fit. He is obsessed with the idea of making his son engineer without judging his real abilities. For him, an engineer is a sign of honour and dignity. The day before the exam, he utters "tomorrow is your chance to make your family name famous." (89). It is his misconception because there are several other respectable means of earning livelihood. But, he gets loans to bear the educational expenses of his son. As a result, the failure of his son is not tolerable to him and he dies leaving his son under the burden of loans. His tragedy emerges because of falsely assuming engineering as a sign of respect and ignoring various other respectable sources of earning with honesty. The father's desire for obtaining popularity, dignity and respect with his son's job is also a mistaken belief. The mistaken beliefs are categorised as reification by Lukacs. Any person does not need to respect others due to their higher rank. A person who serves others is more likely to win their respect. "But these people have travelled a hundred kilometers to meet me. They have had a tragedy." (259). The poor farmer Bishnu Ji throws his turban before Raghav because he serves them through reporting their miseries.

"He took off his turban and put it on Raghav's desk... I told my son you are the bravest, most honest man in this city, Bishnu said, his voice quivering with emotion." (261) ... "The man stood up too, which woke up his son, and bent forward to touch Raghav's feet". (262) 
Thingification and depersonalisation are the prominent traits of some characters in the novels. The failure of Gopal extinguishes kind feelings from his father's heart and he expresses his much anger. "My father's expression changed. He had the look every child dreads. The look that says, "I brought you up, now see what you have done! A bullet in the head is preferable to that look." (32). He shows his paternal love for his son only when the latter is ready to obey him by intending to become an engineer. A respectable job of his son is a necessary condition for instigating his kind feelings towards his son. It is thingification and depersonalisation of Gopal because he is forced to be involved in an activity contrary to his choice. He is not allowed to make his own choice based on his own free will. It is the value of son in terms of income, rank and status. But, it does not mean that the father is cruel or he dislikes his son. It is the system and the law which restricts everyone to follow a particular course. No one can change it and every father wishes his son to obtain a good position in society according to the norms of the system. In this perspective, Lukacs remarks that human beings are slaves to the laws made by themselves. The father prefers the career of his son over everything including his very life and health. His love for his son is based on the laws of the system. It is the system that makes parents ready to sacrifice everything for the successful career of their children and this practice seems natural with human beings, but it is the relational fact of capitalist societies. It cannot be called objectification or commodification of human relationship between the parents and their children because the parents' care for their children's career does not involve the selfishness of the parents. They do not want to draw any materialistic advantages from their children. Rather, the underlying factor is their desire to see their children in good financial and social conditions. This practice is for the betterment of their children.

The feelings of deprivation in his childhood cultivated Gopal's mind in such a way that he considers richness the only inevitability of life. Gopal thinks that richness is the only thing which a person needs in this world. His whole concentration is on the achievement of money and Aarti. In his view, success lies with richness. It is the pursuit of false values because wealth, money and richness are not the only things for which a person needs to struggle. Raghav tries to remove this shadow of falsification from his eyes. "It's not about education, Gopal. It's the person you have become. I can't believe it." In response, Gopal laughs and compares himself with Raghav sarcastically. "Rich. Successful. Hard to believe, huh? The person who cleared JEE is unemployed." (195). Unlike him, Aarti does not believe on the charms of wealth shown by him. About Raghav's newspaper, Gopal remarks "It will never make money." Aarti answers "Money isn't everything." Gopal further states, "Easy to say that when you are eating cakes in a five-star hotel". (198). It means poverty is also a responsible factor in reifying Gopal's mind. But, Aarti thinks that people should choose their careers according to their own choice and desires. "Everyone should follow their heart." (198). It is the rejection of reification. Certainly, following one's own desires prevents dehumanisation and depersonalisation caused by acting upon the decisions of others. But the achievement of desires is largely available to the rich and Gopal is also right to some extent. Believing on the noble values, Aarti marries Raghav. The bond of marriage between them is almost a disclosure of reification on Gopal. It startles him to think about the value of man irrespective of wealth and he begins to ask again and again that if he is a good person.

Poverty contributes to reification because both Gopal and his father develop their reified ideas under the shadows of poverty. A poor is more likely to perform activities contrary to his will and become depersonalised like things by acting against his own choice. Comparatively, having the rich background, Aarti wants to work to fulfill her desire. She intends to become air hostess to see the world. "They fly everywhere. I want to see different places." (16). Simply, the needs of the rich are already fulfilled, and they are in the pursuit of their desires, while the poor usually struggle to meet their needs and in the process the latter are more likely to accept professions against their wishes. The acceptance of a work against one's own wishes and without the involvement of one's own choice is an aspect of depersonalisation and dehumanisation. The dehumanisation is so horrible that sometimes the people, whose freedom to act is denied, commit suicide in a state of extreme despair. Manoj Dutta puts an end to his life by hanging himself with the ceiling fan after his failure in the forced activity of exam. Gopal's father does not give his son the right to act according to his own choice. Having misconception about the security of his son's future in engineering job only, he forces his son into a wrong direction and collapses himself. Gopal expresses his disappointment about his way of living in Kota. "Anyway, how's life. I hate it here." (62). The dehumanised people are often not satisfied with their life-style because they are not free in their actions and they act to fulfill the wishes of others. They are usually marginalised. Gopal's friend Prateek expresses his dissatisfaction in these words. "We don't have a home. We are like people stuck in outer space. No home, no school, no college, no job. Only Kota." (79). The statement suggests that Kota is the city where they are compelled to live against their own choices, but for what purpose. Prateek and Gopal are obliged to live in Kota to make their respective careers because they need to compete in society for survival. The competition is in accordance with the laws made by human beings in capitalism. As Gopal indicates that study is 
necessary to live for a poor boy. "I wanted to study, I wanted to live." (86) This slavery of the laws made by man himself is pointed out by Lukacs.

Poverty and depersonalisation have a close affinity with each other. A poor person usually lives with limited desires. His personality is often disappointed in poor circumstances. Similarly, Gopal is not satisfied with little money and he cannot afford the expenses of his calls to his beloved. "I scolded myself for spending too much on calls." (72) His weak financial status does not allow him to follow his emotions and desires. Thus, a gap appears between the emotional and rational states of his personality. Rationalisation is an intellectual capacity. It normally lacks emotions. It is seen in Gopal's preparation for exam. It is the imposed activity on him for competing in the world of capitalism. The laws of capitalism imply to be rational according to one's affordability, but his extreme love for Aarti compels him to pursue his emotions. In a state of this alienation between his emotions and rationality, he is unable to follow his studies. It is the result of dehumanisation, because his full concentration can hardly be involved in an imposed activity, while the object of his feelings is away from him. The depersonalisation is not seen in the character of Raghav because he works to fulfill his own desire and his decisions are based on his own choices.

The institutions where Gopal goes for coaching do not seem educational institutions. They are like business markets and the students are dealt like clients. These institutions are always busy in extracting profits from the students. They do not consider any compulsion or poverty of any student. No one is ready to have pity on the poor circumstances of Gopal. As a matter of fact, Gopal is used by them like a thing from which maximum amount of profit is extracted. Some agents of the institutions begin to quarrel with each other and pull Gopal to their own respective institutions to be admitted there. He is more a commodity than a human being for them.

MLA Shukla ji extremely believes on the power of money. In his opinion, everyone can be bought with money. The activity of sailing and purchasing is not apt to human beings. It is a thing-like handling of human beings, but Raghav is not bought by Shukla. Gopal remarks about him "He can't be bought sir." But Shukla thinks "everyone has a price." (239). It is a commodification of human beings because he falsely believes that every person has his own price like a commodity. It is the misconception of Shukla and thingification of human beings at the same time.

In a state of mistaken beliefs, reversal of values is more expected. As the people generate false assumptions in their minds, they attach the false values with them also. As a result, objectification or commodification of human relationship appears because an unnecessary weightage is given to things and human beings are underestimated. Things, money and property are regarded more valuable than human relationship. The novelist Terry Pratchett writes "evil begins when you begin to treat people as things". (2017) Gopal's uncle Ghanshyam waits for the approach of his brother's death to usurp his land. "I think he feels I will die soon. It will be easier to resolve afterwards, anyways." (95). For Ghanshyam, property is more valuable than his real brother. At the death of Gopal's father, the lawyer Dubby offers three lakhs as a price of the same land whose price offered by Ghanshyam ten years ago was ten lakhs. But now, Ghanshyam uncle reduces the price as he knows that Gopal desperately needs money. It is the best example to illustrate that money is more valuable than real relationship. Money is a fetishised object and Gopal's uncle is its worshiper. He has no sympathy for his orphan nephew and tries to gain the maximum profit at the critical stage. The preference of money and property over human beings is an illustration of reification. Similarly, to give money extra importance beyond necessity is also reification. Gopal speaks, "Money, I want to make lots of money." (150). Raghav wants honest means of earning and money is not the only thing of concentration for him. "I can't be part of a corrupt enterprise." (163)

Gopal and his father believe on individualistic achievements of people. In the pursuit of individualistic goals, a person limits himself to his own personality only. To consider individualistic custom a part of human temperament is a facet of reification. This practice creates lots of problems in society. It makes people selfish. In a state of selfishness, no one pays any heed towards the miseries of others. Consequently, the helpless and incompetent people suffer and the need for altruistic spirit arises. Hence, it is a mistaken belief to think that everyone is selfish and limited to his/her own interests only. As, one aspect of reification is concerned with considering any relational truth a general phenomenon, limiting oneself to one's own advantages only is a category of reification. On the contrary, the fact is that a person lives in society and sometimes he should think about the needs of others without caring about his own selfish designs. It means society needs some practice of altruism also. Raghav is a good example of altruism who works to eliminate the evil from society and wants to bring revolution in the society. "I'm here to change." (100). Gopal is of the view that "Nobody can change anything." It is a combat between altruistic and individualistic forces. At the end of the novel Gopal retreats and paves the way for the anticipated revolution by supporting Raghav silently. It suggests that a society almost always needs some people to ameliorate and change it. This fact indicates that if everyone begins to follow his 
own selfish aims, a situation of turmoil and mess is more likely to happen. This wrongness of perception is overcome by Gopal at the end. Gopal remains upset and disturbed in spite of huge wealth, while Raghav is happy with little wealth. It indicates that satisfaction and calmness do not depend upon wealth, they depend on goodness, rightness and altruistic achievements.

The newspaper revolution 2020 is actually a predictable revolution against reification. The people are victims of false consciousness and blindness to reality. The real causes of upheavals and corruption are hidden to them. Journalism reveals the truth and brings awareness in the society. But, some people like Gopal and the followers of Shukla deliberately accept blindness. As Gopal turns off the television when Raghav was giving interview. "I turned off the T.V. I couldn't take his bullshit anymore. Neither could Shukla's men." (244). In a state of blindness and selfishness, the people support the MLA Shukla Ji and destroy Raghav's office. It is their blindness that they cannot understand their savior Raghav. Raghav is the rescuer of the whole society and he attempts to decontaminate it from corruption. The corruption is a result of greed and selfishness. The people ignore the corruption of Shukla because they assume that everyone is selfish and has a right to make money. It is their misconception. Had they imagined corruption a serious moral flaw, they would have regarded Shukla accountable for it. It suggests that corruption is an outcome of reification and the newspaper revolution 2020 is an effort to eliminate the reification existing in the society. Raghav works within the parameters of capitalism. $\mathrm{He}$ is not socialist, and his efforts are not anticapitalistic. Therefore, his work is to change the society within the limits of capitalism.

Gopal's achievements are individualistic and Raghav's are altruistic. The novel reveals the fact that higher aim in life to do something better for the whole society is more valuable than the individual success. Extreme degree of selfishness is harmful for society. Shukla harms society, but Raghav works for humanity and gains real satisfaction through altruism while Gopal is still dissatisfied, drinks and asks if he is a good man. Corruption is a form of dishonesty. It is the loss of human values. This is the reason that Gopal's conscience pricks him. There is no question of alienation in Raghav's life, while Gopal's personality is emotionally disturbed. It is the indication that the prevalent trend about the selfishness of human nature is based on false consciousness. Raghav expresses his enthusiasm: "we are passionate about our work." (243)

Some false values are considered real by Gopal. He wants to be a rich person without caring about honest or dishonest means. He gives envelops as bribe, but his spiritual satisfaction lies with Aarti whom he loses in the pursuit of physical pleasure. His ultimate target is to be rich which he attains. But, he loses his spiritual pleasure in the process. His success is the satisfaction of the partial part of his personality. On the contrary, Raghav limits the achievement of property and wealth to his needs only. He honestly earns to meet his needs of survival. His earning is not the ultimate end of his life, as he has a virtuous purpose. Therefore, his values are real, while Gopal's are false.

At the end, Gopal admits "Your career is different from others. You can't measure it in money. In terms of helping people you are doing quite well." (287) About himself, he remarks with disappointment. "I looked around my big house as empty as my soul." (290) Gopal recognises that living for accumulation of wealth is a false value. It is a type of reification. "I will try to fix the system. I am sick of giving envelops to people... everyone must sacrifice for it. Gopal said." (295)

\section{Conclusion}

Reification is a depiction of social practice in a capitalist society. It is generally a misconception about social relations, human values and some other aspects of capitalism. It is all-pervasive phenomenon in the capitalist society delineated in Revolution 2020. Various characters in the novel are its victims. Gopal's mental distraction is caused by reification because he loses Aarti owing to imitating the manners of the rich people without grasping the moral truth. His personality is divided between reified world and the passionate aspect of his self. Different aspects of capitalism like individualism and selfishness lead to reification. Reification is an ideological state of capitalist society and akin to false consciousness. It is a blindness about comprehending the facts. The novel reflects the various aspects of reification. It is a revolution against reification because the newspaper launched by Raghav spreads the awareness to reveal the social reality. Chetan Bhagat gives the message implicitly that it is necessary to get rid of reification to purify the society from corruption.

The applicability of the theory of reification on the story discloses the fact that honour lies in doing some services for others and only selfishness cannot be the sole aim of human life. Gopal is not successful in winning the respect of the people around him. He fails in marrying his beloved and is limited to himself, but Raghav is visited by the common people who respect him. The character of Gopal informs us that the people who accumulate wealth only are not successful. They are victims of false consciousness. Wealth facilitates human life 
but sometimes it causes problems.

The history of Gopal and his father informs that erroneous beliefs and misconceptions often bring tragic events in human life. The relationship between Gopal and his father verifies that the laws of capitalism are more powerful than the parents' love for their children since the parents' love is steered by the conditions of capitalism.

The poor characters in the novels are especially the victims of dehumanisation and depersonalisation. The story shows a conflict between individualism and altruism. Individualistic achievements are witnessed as the struggles of reified mind while altruism is offered as a need of society and a source of spiritual pleasure. The theme of corruption is a result of reification and the newspaper launched by Raghav is an attempt to get rid of reification. Reification is an ignorance against which Raghav spreads awareness. The novel offers a contrast between the true and false values.

The element of reification is not limited to the Indian society only, as represented in Revolution 2020. Some English novelists in Pakistan have also depicted it. Zulfikar Ghose and Shoakat Siddique reflect it in their novels: The Murder of Aziz Khan and God's Own Land respectively. It gives impression that reification is almost a social issue related to multiple capitalist societies. Many people are normally influenced by it either consciously or unconsciously and its various aspects can be observed in real life as well.

\section{References}

Belsey, C. (2005). Textual analysis as a research method. In G. Gabriele (Ed.), Research methods for English studies (pp. 157-173). Edinburgh: Edinburgh U.

Bhagat, C. (2011). Revolution 2020. India: Rupa pvt ltd.

Bottomore, T.(1991). Reification. A Dictionry of Marxist thought (2nd ed.). Oxford: Blackwell.

Burris, V. (1988). Reification: Marxist Perspective. California Sociologist, 10(1), 22-43. Retrieved from pages.uoregon.edu/vburris/reification.pdf

Feenberg, A. (2015). Lukács's Theory of Reification and Contemporary Social Movements. Rethinking Marxism, 4(27), 490-507. https://doi.org/10.1080/08935696.2015.1076968

Geuss, R. (2008). Philosophical anthropology and social criticism in reification: A new look at an old idea. In M. Jay (Ed.). Oxford: Oxford UP.

Honneth, A. (2005). Reification: A recognition-theoretical view: The tanner lectures on human values. University of California Berkeley (pp. 93-94). Retrieved from https://www.google.com/search?q=Reification\%3A+a+recognition-Theoretical+view\%3A+The+Tanner+Le ctures + on + Human + Values\&ie $=$ utf- $8 \&$ oe $=$ utf- $8 \&$ client $=$ firefox-b

Lukacs, G. (1971). Reification and the consciousness of the proletariat. History and class consciousness: Studies in Marxist dialectics (pp. 83-86) (Rodney Livingstone, Trans.). Cambridge, Massachusetts: Merlin.

Marx, K. (1959). Capital: A critique of political economy. USSR: Institute of Marxism-Leninism.

Nussbaum, M. (2000). Objectification, in sex and social justice. Oxford/New York: Oxford university press. https://doi.org/10.1093/acprof:oso/9780195112108.001.0001

Pitkin, H. F. (1987). Rethinking Reification. Theory and Society, 2(16), 263-293. https://doi.org/10.1007/BF00135697

Postone, M. (2003). Lukács and the Dialectical Critique of Capitalism. New Dialectics and Political Economy (pp. 78-100). UK, Palgrave Macmillan \& Springer Link. Retrieved from http://link.springer.com/chapter/10.1057\%2F9780230500914_5

Pratchett, T. (2017). Thing-ification: Why the human face of work needs to be brought back in. The conversation. Retrieved from http://theconversation.com/thing-ification-why-the-human-face-of-work-needs-to-be-brought-back-in-7500 0

Smith, A. (2005). An inquiry into the nature and causes of the wealth of nations. An electronic classics series. Libgen PDF. Retrieved from http://libgen.io/ads.php?md5=C9DBF40FFCB4E037E786359E0D85BFF9

Walker, D., \& Gray, D. (2007). Historical dictionary of Mrxism. United States of America: The scarecrow.

Woodard, J. W. W. (2005). Intellectual Realism and Culture Change: A Preliminary Study of Reification. Minneapolis: Sociological, 2, 423-466. https://doi.org/10.2466/pr0.97.2.423-466 


\section{Copyrights}

Copyright for this article is retained by the author(s), with first publication rights granted to the journal.

This is an open-access article distributed under the terms and conditions of the Creative Commons Attribution license (http://creativecommons.org/licenses/by/4.0/). 